\title{
Grazing effects of the bulk density in a Natraquoll of the Flooding Pampa of Argentina
}

MIgUEL A. TABOADA AND RAÚL S. LAVADO

\section{Abstract}

The influence of graxing by cattle on soil bulk density was studied in a typic Natraquoll of the Flooding Pampa of Argentina for a period of 33 months, by comparing a grazed situation to an enclosure deferred from graxing for 7 years. Floods took place in this period as usual. Bulk density (BD) at $-33.3 \mathrm{kPa}$ of water retention varied from 1.00 to $1.11 \mathrm{Mg} \mathrm{m}^{-3}$ in the ungrazed soil and in the grazed soll from 1.04 to $1.16 \mathrm{Mg} \mathrm{m}^{-3}$.

Environmental factors were the primary agent controlling BD; only in some periods were there significant differences between treatments. Slight increases in BD occurred under graxing after the recession of the flood water, and significant decreases occurred in the ungrazed soil during the large and sudden falls in water content. In this case the effect of trampling, therefore, would consist mainly of impeding the decrease in BD. No compaction was observed in periods when no flood occurred or while soll remained submerged in water.

The results indicated that the variations of bulk density caused by cattle trampling were superimposed on those produced by floods and showed an interaction between the effects of land-use and the particular environmental conditions of the region.

The Flooding Pampa is a subhumid low, very flat plain. Its $90.000 \mathrm{~km}^{2}$ are mostly covered by halo-hydromorphic soils, the most conspicuous being Natraquolls (INTA 1977). The region is affected by recurrent floods caused by an excess of water: percolation, surface movement, and evaporation are less than rainfall. Soils remain saturated and ponded most years from winter to late spring, and exceptionally in autumn; they are dry in some summers. Floods and droughts sometimes follow each other. Because of several constraints, agriculture is limited and the dominant land-use in the region is the production of beef cattle on natural grasslands. Cattle remain over the field all year, including those periods when soil is very wet. Trampling in these conditions is usually considered a severe damage factor in surface structure of grassland soils (Davies 1985, Scholefield and Hall 1986).

Trampling by cattle is reported by the literature as causing increases in bulk density by compaction in the soil surface (Heady 1975, Lull 1959, Van Haveren 1983, Warren et al. 1986, Willat and Pullar 1983). Nevertheless some results are in disagreement with this opinion. Laycock and Conrad (1967) found that some increases in bulk density may be ascribed to the lower water content that grazed soils usually have (Gifford and Hawkins 1978); Van Haveren (1983) showed that not all soils may be compacted by trampling because of the high sand content of some soils; and Lagocki (1978) even found that bulk density decreased when trampling was performed on a soil with high water table. Another subject under controversy is the time required for the recovery of soil structure, as measured by the decrease of bulk density after compaction. For example, Braunack and Walter (1985) found long periods for recovery, while Warren et al. (1986) showed that shorter terms were required.

The factors causing these differences are obviously related to different soil properties, environmental conditions, and grazing intensities. They make it difficult to transfer results from one site to

\footnotetext{
Authors are with the Departamento de Ecologia, Facultad de Agronomía, Universidad de Buenos Aires, Avenida San Martín 4453, 1417 Buenos Aires, Argentina.

Manuscript accepted 24 May 1988.
}

another. In the case of the Flooding Pampa, despite the economic importance of grazing, local literature is very scarce. Rusch and León (1983), for instance, attributed changes in the floristic composition of a natural grassland to soil compaction by trampling.

Bulk density is a commonly used parameter of soil porosity, giving an effective indication of the compaction-regeneration processes (Bullock et al. 1985). The objective of this study was to evaluate the effects of cattle grazing upon soil bulk density in the Flooding Pampa region of Argentina. The implications for stock management are also considered.

\section{Materials and Methods}

\section{Study Area}

Research was carried out in an area located in the middle of the Flooding Pampa near the town of Casalins (Buenos Aires Province), in which floods occur most years. In the period under study (from October 1983 to July 1986) floods submerged the soils with a few centimeters of water in winter-spring 1984 and 1985 and in autumn 1986. There were no floods in 1983.

Vegetation of the area is a natural grazed grassland community characterized by Piptochaetium montevidensis, Briza subaristata, Eclipta bellidioides, and Mentha pulegium (Perelman et al. 1982). It covers more than $70 \%$ of soil surface. Grasses are sparsely distributed over the soil and are stratified in the first $10 \mathrm{~cm}$ of plant canopy (Sala et al. 1986). The range is mainly devoted to the production of beef cattle. Dominant soil is a typic Natraquoll, General Guido series, moderately saline phases. The soil is characterized by a tough clayey and natric B2t horizon. Conversely, the $0.12 \mathrm{~m}$ thick A1 horizon is loamy (clay \%: 23.60 ), slightly acid (pH 6.20) with high organic carbon percentage (3.20). This horizon has a high swell-shrink capacity as its clay fraction has 30 to $50 \%$ of smectitic materials, causing bulk density to fluctuate with changes in soil water content. Taboada et al. (1988) related soil bulk density to moisture content by the function:

$$
\mathrm{BD}=1.20+0.0008 \mathrm{GW}-0.00016 \mathrm{GW}^{2} \mathrm{r}=-0.95
$$

where $B D$ is soil bulk density and $G W$ is gravimetric soil water percentage.

Other morphological, mineralogical, and chemical properties of this soil have been published elsewhere (Lavado and Taboada 1985, Taboada and Lavado 1986, Taboada et al. 1987).

\section{Treatments}

The bulk density and water content of soil were measured in a grazed location and at a location excluded from grazing for 7 years prior to initiation of the study. The locations were not replicated . The grazed field was a natural grassland which had never been ploughed, but had been grazed year-round for more than a century. During the study period the mean stocking rate was 1.06 cattle ha ${ }^{-1}$ year $^{-1}$. This rate is representative of most ranges of the region. The ungrazed enclosure was a 4-ha field fenced and surrounded by the cattle range; grazing had been excluded from it since 1976. Grazing exclusion resulted in the replacement of a large number of small tussocks by a few large ones. Total biomass, mainly standing dead, increased steadily; litter accumulated. Another major effect was the disappearance of some native planophile species and most of the exotics from the enclosure (Sala et al. 
1986). Nevertheless the soil only showed significant reductions in salt content, but not in organic matter, total nitrogen, and available phosphorus contents (Lavado and Taboada 1985, 1987).

\section{Sampling and Analysis}

Sampling was carried out in the Al horizon. Five undisturbed soil cores $(9 \mathrm{~cm}$ in diameter and $10 \mathrm{~cm}$ in depth) were taken at random from each treatment on 22 dates during the period under study. Sampling was performed carefully because of the extreme soil water content found along the time in each core. Bulk density was determined by the core method (Blake 1965) and gravimetric soil water content by the oven-dry method. Volumetric soil water content (VW) was calculated from them. The depth affected by animal hooves was evaluated by additional bulk density samples taken at the $0-4,4-8$, and $8-12 \mathrm{~cm}$ depths of the $A 1$ horizon using 6 $\mathrm{cm}$ diameter and $4 \mathrm{~cm}$ depth cores. Five samples were taken at random from each treatment in November 1984 and June 1985.

In order to separate the effect of compaction by animal hooves from that caused by decreases in soil water content (Laycock and Conrad 1967), measured values of bulk density were adjusted to a fixed soil water content (Perrier et al. 1959). In this case bulk density was standardized at -33.3 kilo Pascal $(\mathrm{kPa})$ of water retention (29.96\% in this horizon), by means of the slopes of equation (1). This procedure was judged to be reliable because of the very high and statistically significant $(\alpha \leq 0.001)$ correlation coefficient found for equation (1).

Soil surface strength was measured in September, November, and December 1984, using a Proctor penetrometer (Davidson 1965). In each month, 20 measurements were performed following a zig zag path over uncovered soil surfaces in each treatment.
Results were statistically appraised by analysis of variances (ANOVA). When significant differences in BD were found between dates, the Tukey test was used to separate the means.

\section{Results and Discussion}

Volumetric water content and bulk density at $-33.3 \mathrm{kPa}$ in the Al horizon are shown in Figure 1. Flood periods are also included.

Mean VW ranged from 17.06 to $40.79 \%$ in the ungrazed soil, and from 19.09 to $42.44 \%$ in the grazed soil. Only in the first summer of the studied period (November 1983 to January 1984) was soil dry. The rest of the time it remained with moderate to very high water contents. According to Scholefield and Hall (1986), under these conditions soil surface damage by cattle trampling is likely to occur.

Mean BD ranged from 1.00 to $1.11 \mathrm{Mg} \mathrm{m}^{-3}$ in the soil of the enclosure where cattle were removed from 1976, and from 1.04 to $1.16 \mathrm{Mg} \mathrm{m}^{-3}$ in the soil under grazing. These values were somewhat low, but consistent (De Kimpe et al. 1982) with the high organic carbon content of the Al horizon. Different behavior was observed in $B D$ with time in both treatments. In the ungrazed soil there were lower and significant values on 3 dates (November 1983, January and December 1985). They were reached after the soil underwent great loss of water as its $\mathrm{VW}$ showed a sudden fall from a previous very wet condition (it was saturated with water in 1983 and flooded both in 1984 and 1985). The sudden decreases in soil water content seemed to be associated with the parallel decreases in BD. This relationship cannot be explained easily, and further research is needed; but the sequence of events after the autumn 1986 flood provides indirect evidence of the active role of the sudden falls in
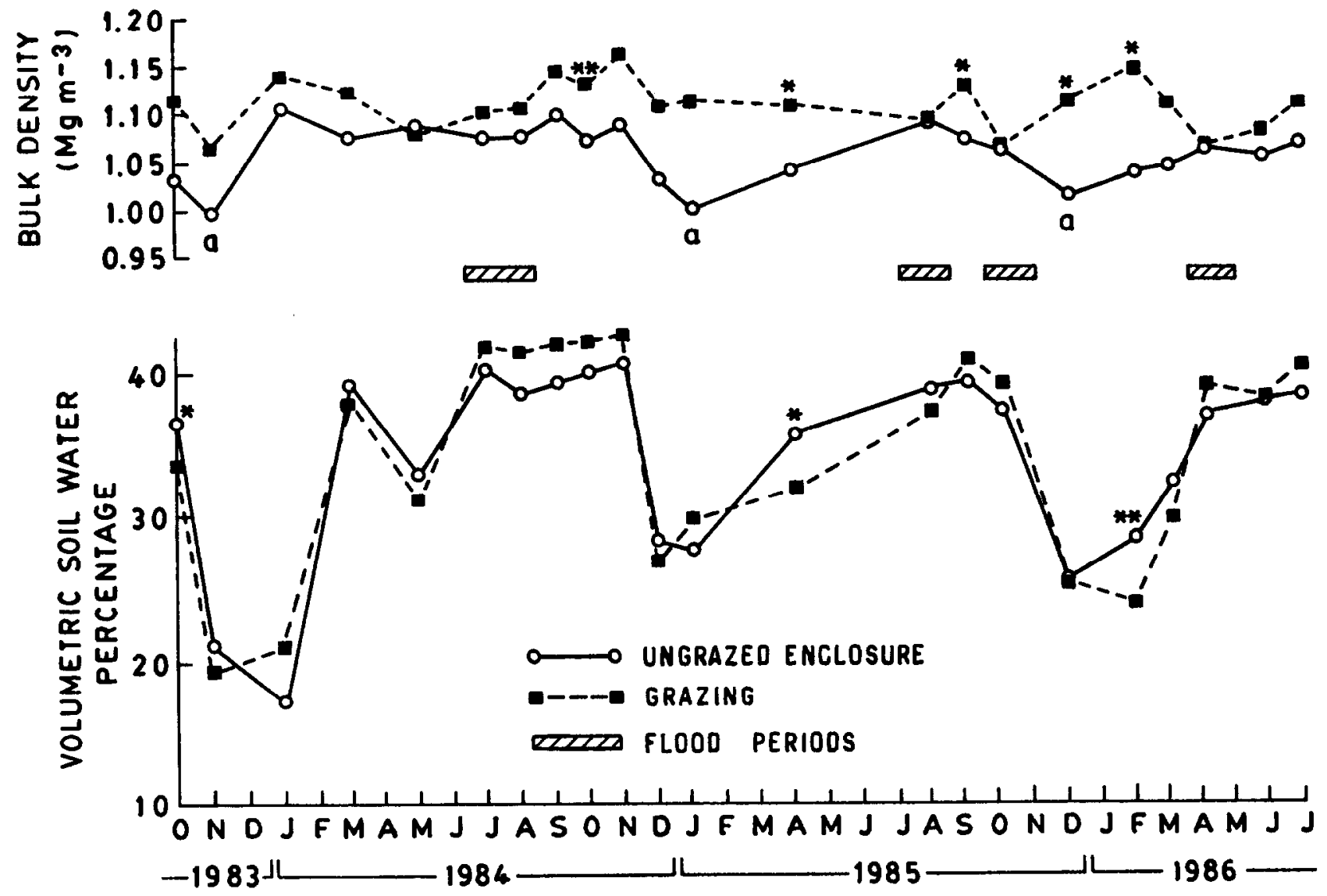

Fig. 1. Bulk density at $-33.3 \mathrm{kPa}$ and volumetric soil water content in the Al horizor, and floods during the studied period. Statistical dfferences between dates are indicated by a $(0.05$ probability level) and between treatments by $a *$ or $a * *(0.05$ or 0.01 probability levels respectively). 
water content. After the flood water receded, there was no decrease in volumetric water content as winter began. Presumably, as a result, BD did not decrease either. The grazed soil did not show significant decreases in $\mathrm{BD}$ with time, despite its water content behaving similarly to that of the ungrazed soil.

Only in some dates (for instance November 1984, September and June 1985) were processes of compaction reported by most of the literature (Heady 1975, Lull 1959, Van Haveren 1983; Warren et al. 1986, Willatt and Pullar 1983). These processes were reflected by slight increases in BD in the grazed soil, which appeared after the receding of the flood water. Soil compaction by cattle trampling was also verified by measurements of soil surface strength (Table 1). Approximately two-fold increases were observed in the grazed

Table 1. Soil surface strength as measured by the proctor penetrometer in 1984.

\begin{tabular}{lcc}
\hline \hline & \multicolumn{2}{c}{ Mean Soil Strength (kPA) } \\
\cline { 2 - 3 } Dates & Ungrazed & Grazed \\
\hline September & $450 * *$ & 940 \\
November & $470^{* *}$ & 690 \\
December & $3710^{* *}$ & 6440 \\
\hline
\end{tabular}

**Differences between mean values are significant at the 0.01 probability level.

soil as compared to the ungrazed. On the other hand, a highly significant decrease of soil strength occurred in the soil under grazing from September 1984, when a flood just ended, to November 1984. The loss of soil strength was not attributable to differences in water content between dates (Fig. 1), but probably to a process of mellowing or softening of soil structure (McKenzie and Dexter 1985, Utomo and Dexter 1981). This process consists in partial slaking of soil aggregates which weaken but do not completely fragment into smaller particles. It takes place after the soil is carried to very high water content, as occurred in this study after flooding. Besides, soil softening at surface is largely enhanced by the remoulding action of animal hooves, thus reflecting the failure of wet soil to accommodate a load (Mullins and Fraser 1980). Both mechanisms-soil mellowing and remoulding by trampling - may be pointed out as the direct causes of the compaction found in the grazed soil after flooding. Interesting to note, no flood occurred in 1983 and soil BD did not increase under grazing. This lack of difference between treatments was maintained for several months, until the recession of the next flood.

The significant decrease in BD in the soil of the ungrazed enclosure was the other source of differences between treatments. In this case the effect of trampling would consist mainly of impeding these decreases during the sudden falls in water content. On the other hand no significant differences in BD were found while the soil remained submerged by water. This accords with results of Saini et al. (1984), who found that soil compactibility under a given load tends to decrease at the highest water content, and subsequent increases in bulk density are unlikely to occur.

Periods with differences in BD never lasted more than a few months, being shorter than those long-time processes shown by Braunack and Walter (1985). The cycles of wetting and drying of this soil probably played an active role in the recovery of porosity (Bullock et al. 1985, Newman and Thomasson 1979, Oades 1984), but the disappearance of differences in BD seemed to be more specifically related to the soil rewetting after the summer (Fig. 1). In addition, several properties of this soil that maximize the aggregation of soil particles (Oades 1984) would prevent deleterious effects due to this kind of land-use: its unploughed condition, its very high content of organic carbon, and according to Doll and Deregibus (1986), the great amount of below-ground biomass concentrated in the Al horizon.

Bulk density in 4-cm layers of the A1 horizon is shown in Table 2. In November 1984 when BD of the whole horizon showed
Table 2. Bulk dendity in $\mathbf{4} \mathrm{cm}$-layers of the $\mathrm{Al}$ horizon.

\begin{tabular}{lccc}
\hline \hline & & \multicolumn{2}{c}{ Mean Bulk Density $\left(\mathrm{Mg} \mathrm{m}^{-3}\right)$} \\
\cline { 3 - 4 } Dates & Layer $(\mathrm{cm})$ & Ungrazed & Grazed \\
\hline \multirow{3}{*}{ Nov. 1984 } & $0-4$ & $0.96 *$ & 1.00 \\
& $4-8$ & $1.20 *$ & 1.29 \\
& $8-12$ & 1.28 & 1.30 \\
June 1985 & $0-4$ & 0.97 & 0.99 \\
& $4-8$ & 1.23 & 1.24 \\
& $8-12$ & 1.29 & 1.28 \\
\hline
\end{tabular}

-Differences between mean values in same row are significant at the 0.05 probability level.

significant differences between treatments (Fig. 1), they appeared only in the 0-4 and 4-8 cm layers. In June 1985 when there were no differences, none of $\mathrm{Al}$ horizon layers presented differences in BD either. Trampling influence occurred, then, within the first 8 centimeters of soil depth.

\section{Conclusions}

The environmental conditions of the Flooding Pampa, particularly its floods and the water regime of its soils, were associated with variation in soil bulk density and were shown to be the main cause for the lack of severe and long-term damage by cattle trampling. It is difficult to attribute to soil compaction a major influence on the floristic composition of this natural grassland community. Other already observed modifications in soil properties (Lavado and Taboada 1987) could be more important.

The results showed that the variations in BD caused by cattle trampling were superimposed on those produced by climatic and soil characteristics. There were times when grazing effects were detectable, but for a longer time frame, grazing effects were completely overriden by inherent characteristics operating in the Flooding Pampa. This finding may be applicable in selecting grazing systems appropriate for flooding soils; stocking rates must be regulated in periods when it is expected that trampling may affect the soil.

\section{Literature Cited}

Blake, G.R. 1965. Bulk density. In: Black, C.A. (ed.). Methods of Soil Analysis". Agronomy Series 9, Part 1, Madison, Wis.

Braunack, M.V., and J. Walter. 1985. Recovery of surface soil properties of ecological interest after sheep grazing in a semi-arid woodland. Aust. J. Ecol. 10:451-460.

Bullock, P., A.C.D. Newman, and A.J. Thomasson. 1985. Porosity aspects of the regeneration of soil structure after compaction. Soil Till. Res. 5:325-342.

Davidson, D.T. 1965. Penetrometer measurements. In: Black, C.A. (ed.) Methods of Soil Analysis". Agronomy Series 9, Part 1. Madison, Wis.

Davies, P. 1985. Influence of organic matter content, moisture status and time after reworking on soil shear strength. J. Soil Sci. 36:299-306.

De Kimpe, C.R., M. Bernier-Cardou, and P. Joliceur. 1982. Compaction and settling of Quebec soils in relation to their soil water properties. Can. J. Soil Sci. 62:165-175.

Doll, U.M., and V.A. Deregibus. 1986. Efecto de la exclusión del pastoreo sobre el subsistema subterráneo de un pastizal templado húmedo. Turrialba 36:337-344.

Gifford, G.F., and R.H. Hawkins. 1978. Hydrologic impact of grazing on infiltration. Water Res. Resour. 14:305-313.

Heady, H.F. 1975. Rangeland Management. McGraw-Hill, N.Y.

INTA. 1977. La Pampa Deprimida. Condiciones de Drenaje de sus Suelos. INTA, Departamento de Suelos, Public No. 154. Bs. As.

Lagock, H.F.R. 1978. Surface soil stability as defined and controlled by a drainage criterion. In: Emerson, W.W.; R.D. Bond and A.R. Dexter (eds.). Modification of Soil Structure. John Wiley \& Sons.

Lavado, R.S., and M.A. Taboada. 1985. Influencia de la exclusión del pastoreo sobre algunas propiedades químicas de un Natracuol de la Pampa Deprimida. Ciencia del Suelo. 3:102-108.

Lavado, R.S., and M.A. Taboada. 1987. Soil salinization as an effect of grazing in a native grassland soil in the Flooding Pampa of Argentina. Soil Use Manage. 3:143-148. 
Laycock, W.A., and P.W. Conrad. 1967. Effect of grazing on soil compaction as measured by bulk density on a high cattle range. J. Range Manage. 20:136-140.

Lull, H.W. 1959. Soil compaction on forest and range lands. Forest Serv. USDA. Misc. Pub. No. 768. Washington D.C.

MeKenxie, B.M., and A.R. Dexter. 1985. Mellowing and anisotropy induced by wetting of moulded soil samples. Aust. J. Soil Res., 23:37-47.

Mullins, C.E., and A. Fraser. 1980. Use of the drop penetrometer on undisturbed and remoulded soils at a range of soil water tensions. J. Soil Sci. 31:25-32.

Newman, A.C.D., and A.J. Thomaseon. 1979. Rothamsted studies on soil structure. III. Pore size distributions and shrinkage processes. J. Soil Sci., 30:415-440.

Onde, J.M. 1994. Soil organic matter and structural stability: mechanisms and implications for management. Plant Soil. 76:319-338.

Perelrann, S.B.; R.J.C. León, and V.A. Dere dbus. 1982. Aplicación de un método objetivo al estudio de las comunidades vegetales de pastizal de la Depresión del Salado (Provincia de Buenos Aires). Rev. Fac. Agron. 3:27-40.

Perrier, E.R., D.R. Nielaen, and J.E. Doan. 1959. Adjustment of bulk density to an oven-dry volume basis. Soil Sci. 88:291-293.

Ruach, G.M., and R.J.C. León. 1983. Sucesión inducida por pastoreo en un pastizal de la Depresión del Salado (Provincia de Buenos Aires). Resumenes XI Reunión Argentina de Ecología. Villa Giardino, Córdoba, Argentina.
Sainl, G.L.; T.L. Chow, and I. Ghanem. 1984. Compactibility indexes of some agricultural soils of New Brunswick, Canadá. Soil Sci., 137:33-38.

Sala, O.E.; M. Oeaterteld; R.J.C. Lebn, and A. Soriano. 1Ss6. Grazing effect upon plant community structure in subhumid grasslands of Argentina. Vegetatio, 67:27-32.

Scholefield, D., and D.M. Hall. 1986. A recording penetrometer to measure the strength of soil in relation to the stresses exerted by a walking cow. J. Soil Sci. 37:165-176.

Taboada, M.A., and R.S. Lavado. 19e6. Características del régimen ácuico de un Natracuol de la Pampa Deprimida. Ciencia del Suelo. 4:66-71.

Taboada, M.A.; R.S. Lavado, and M.C. Camillón. 1988. Cambios volumétricos en un Natrocuol tipico. Ciencia del Suelo (in press).

Utomo, W.H., and A.R. Dexter. 1981. Tilth mellowing. J. Soil Sci. 32:187-202.

Van Haveren, B.P. 1983. Soil bulk density as influenced by grazing intensity and soil type on a shortgrass prairie site. J. Range Manage. 36:586-588.

Warren, S.D., M.B. Nevill, W.H. Blackburn, and N.E. Garza. 1986. Soil response to trampling under intensive rotation grazing. Soil Sci. Soc. Amer. J. 50:1136-1340.

Willatt, S.T., and D.M. Pullar. 1983. Changes in soil physical properties under grazed pastures. Aust. J. Soil Res. 22:343-348. 